\title{
Device Observer Serial Number
}

National Cancer Institute

\section{Source}

National Cancer Institute. Device Observer Serial Number. NCI Thesaurus. Code C69253.

The serial number of an automated observation device. 